\title{
Palmar Dermatoglyphics, a Possible Screening Tool among Some Egyptian Children with Acute Lymphoblastic Leukemia
}

\author{
Nagla M Salamaํㅗ , Somaya A Madkour ${ }^{1}$, Amina Elhalawany², Nermine A \\ AbdelHak ${ }^{1}$
}

\author{
${ }^{1}$ Forensic Medicine and Clinical Toxicology Department \\ ${ }^{2}$ Pediatric Department
}

Faculty of Medicine, Alexandria University, Alexandria, Egypt.

\begin{abstract}
Study of dermatoglyphics has a great importance in judicial and criminal researches. Nowadays its relation to some genetic diseases has an immense application. The patterns of dermatoglyphics have been studied in various congenital disorders like Down syndrome, Klinefelter's syndrome and also in chronic diseases like hypertension, diabetes mellitus etc.

The present study was carried out to demonstrate the association between acute lymphoblastic leukemia among children and palmar dermatoglyphics to assess the possibility of using this association as a screening tool for early prediction of leukemia. The study was conducted on 50 children suffering from acute lymphoblastic leukemia who attended at the Hematology and Oncology Unit, Pediatric Department, El-Shatby Hospital, Main Alexandria University Hospital. Matched healthy controls were selected within the same age group. The dermatoglyphic features (ab-ridge count, atd, tda and dat angles) were measured.

Results: The present study showed a significant relation between palmar dermatoglyphics and childhood acute lymphoblastic leukemia. The patients group had significantly lower atd, tad and abridge with no significant difference as regards adt angle than control group as regards the right hand measurements. On the other hand the patients group had significantly lower atd, adt angles and ab-ridge count and significantly greater tad angle than the control group as regards the left hand measurements. The present study developed an equation for prediction of acute lymphoblastic leukemia in children with an accuracy of $66.7 \%$.

Conclusion: palmar dermatoglyphics can represent non-invasive anatomical marker of acute lymphoblastic leukemia risk facilitating its early detection among children.
\end{abstract}

Keywords Palmar dermatoglyphics. Acute lymphoblastic leukemia

\section{Introduction}

$\mathrm{D}$ ermatoglyphics is the study of friction ridge pattern on the skin of the palm, fingers, sole and toes. The ridge configurations are formed early during embryonic development, so they are genetically determined but can be influenced or modified by environmental factors. After birth it persists throughout the whole life unchanged (Cowger, 1993 and Seiger et al., 2008).

The study of dermatoglyphics was commonly used in judicial and criminal researches (Cole, 2001)., Researches had been made to link dermatoglyphics to anthropology and medical diseases based on genetic aberrations. The specific dermatoglyphic traits were claimed to be inherited as dominant, incompletely dominant, recessive, single gene or polygenic with complete or incomplete penetrance and as a variable expression of genes. Dermatoglyphics has been studied in certain clinical disorders which are associated with chromosomal and developmental defects like mongolism, Turner's syndrome, cardiovascular disease, diabetes mellitus, schizophrenia and ischaemic heart disease (Barbosa et al., 2009, Oladipo et al., 2007, and Wang et al., 2008).

Acute lymphoblastic leukemia represents a malignant disease of unknown origin in which there is uncontrolled proliferation of white blood cell 
precursors. The cells may be B-cell precursors $(\sim 80$ to $85 \%$ of cases) or T-cell precursors $(\sim 15$ to $20 \%$ of cases) (Conter et al., 2004 and Kern, 2002).

Acute lymphoblastic leukemia (ALL) accounts for $75 \%$ of all cases of childhood leukemia. The peak incidence of ALL occurs between age 2 and 5 years with slight male predominance (Gordijn et al.,2012).

Diagnosis of ALL is established by bone marrow biopsy, which shows the leukemic cells infiltration and immunophenotyping performed by flow cytometry on either blood or a bone marrow aspirate (Caroll and Loh, 2011).

Most of the cases of ALL show genetic abnormality, the first fusion gene described in ALL was the Philadelphia $(\mathrm{Ph})$ chromosome which has been demonstrated in about $25 \%$ of adult ALL cases and $3 \%$ to $5 \%$ of paediatric ALL cases (Ravandi and Kebriaei, 2009).

This work was carried out to study the relation between ALL among children and palmar dermatoglyphics to assess the possibility of using the later as a forensic screening tool for early prediction of leukemia.

\section{Methodology}

\section{Subjects}

The study was conducted on 50 Egyptian children aged between 2-10 years old, diagnosed as acute lymphoblastic leukemia who attended during the study period for treatment and follow up at the Hematology and Oncology Unit, Pediatric Department, El-Shatby Hospital, Main Alexandria University Hospital. Diagnosis of the disease was confirmed by bone marrow biobsy, cytochemistry and immunophenotyping.

The study also included a control group composed of 50 aged and sex matched, apparently healthy children. Children with evidence of any other malignancies, congenital diseases, hand deformity, hand cannulated children.

\section{Materials and methods}

Fingerprint inked strips $6 \times 10$ inches, soap and dry towel, white paper A4. Fingerprint inked strips are specially designed for child palm prints identification programs because the ink is easily washable, non-toxic and hypo-allergenic.

Informed consents had been taken from the children's parents or caregivers before obtaining their palmprints.

\section{I- Technique used for taking child's palmprint}

Each child was asked to wash his hands with soap and water. The fingerprint inked strips were pulled apart to expose the ink then the child's palm was placed on the opened strips and pressed firmly especially at the center. This helps to flatten the palm and open much of folds and creases. The inked hand was placed on the white paper and fingers of the hand and the center of the palm were pressed firmly then the printed hand was rotated to the outside, until it is approximately vertical and lifted to obtain the full ridge pattern of the palm (Cowger, 1993).

It was difficult to take palmprint of children less than 2 years. They have relatively small sized hands which will make their palmprint parameters analysis inaccurate. The absence of their cooperation to open their hands to take their palmprints was another cause to exclude this age group from the present study (Wertheim, 2011).

\section{II- Examination and analysis of printed palmprints}

The paper having the child's palmprint was scanned immediately (to eliminate the possibility of being changed by environmental factors) with resolution 600 dots per inch (dpi) and analysis of the dermatoglyphics parameters had been done using AutoCAD classic program, version 2007.

Quantitative analysis of the following palmprint dermatoglyphics was done:

1- The triradii (a, d, b, and t) were identified. (figure $1 \mathrm{a}$ and $1 \mathrm{~b}$ ) (Barbosa et al., 2009). The triradial point is the meeting point of three ridges that form angles of approximately 120 degrees with another (Schauman B and Alter M 1976).

2- Three lines were made to connect the three triradii 'a', 'd' and ' $t$ '. (figure2)

3- The angles at triradii ' $a$ ', ' $d$ ' and ' $t$ ' were measured.

4- Another line was drawn between triradii ' $a$ ' and ' $b$ ' where ab- ridge count (number of ridges crossing the line drawn between triradii ' $a$ ' and ' $b$ ') had been counted. (figure3)

When two ' $a$ ' or two ' $d$ ' triradii were encountered, the more radial and more ulnar triradius, respectively, were considered. When more than one ' $t$ ' triradius was encountered in a single print, the more proximal triradius was used in angle measurement.

AutoCAD classic program was used for measuring the atd, adt, tad angles. ab-ridge count was counted better and more easily by zooming in the scanned photo.

\section{III- Statistical parameters}

Data were subjected to statistical analysis using the SPSS software package version 20.0. Statistical analysis was done to obtain the mean, the standard deviation; the standard error of each mean and for comparison between the different groups involved in this study. A high value of the standard error of estimate (SEE) indicates a low degree of accuracy. Coefficient of correlation for measurement of the strength of the association between two variables is calculated by Pearson's product-moment coefficient of correlation (r) (Chan, 2004). 


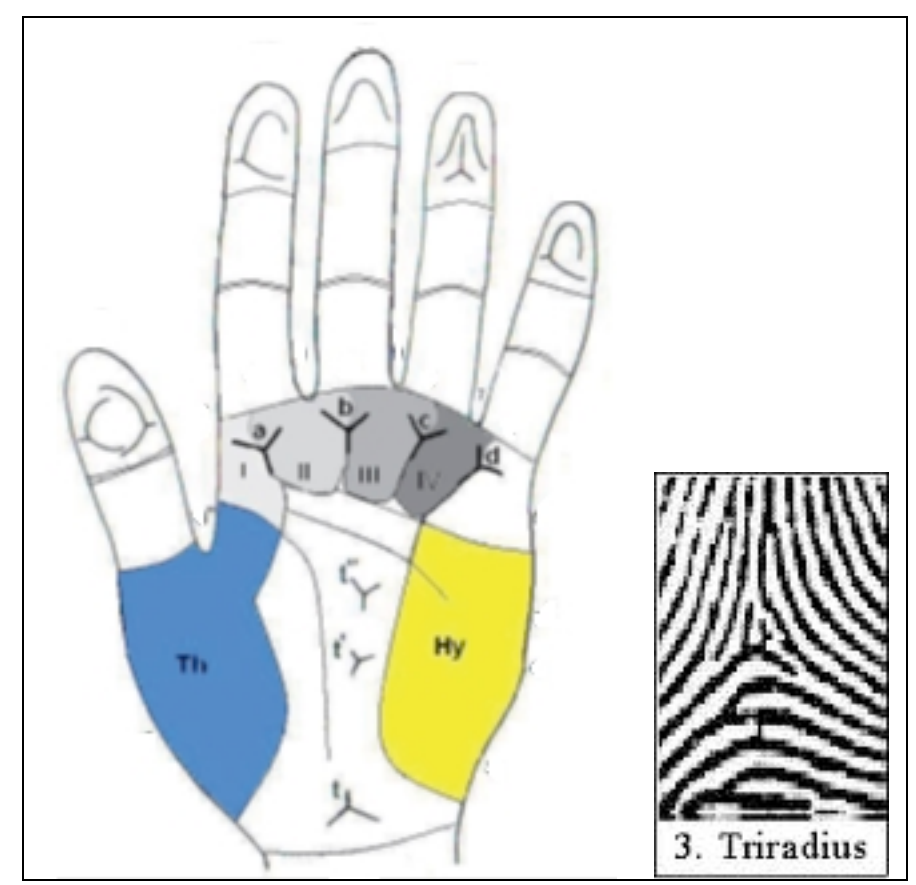

Figure 1a: Diagram showing the main triradii of the palm: a, b, c, $d$ and $t$. Axial triradius can be $t$, $t^{\prime}$ and $t^{\prime \prime}$ according to its position. (Barbosa et al., 2009).

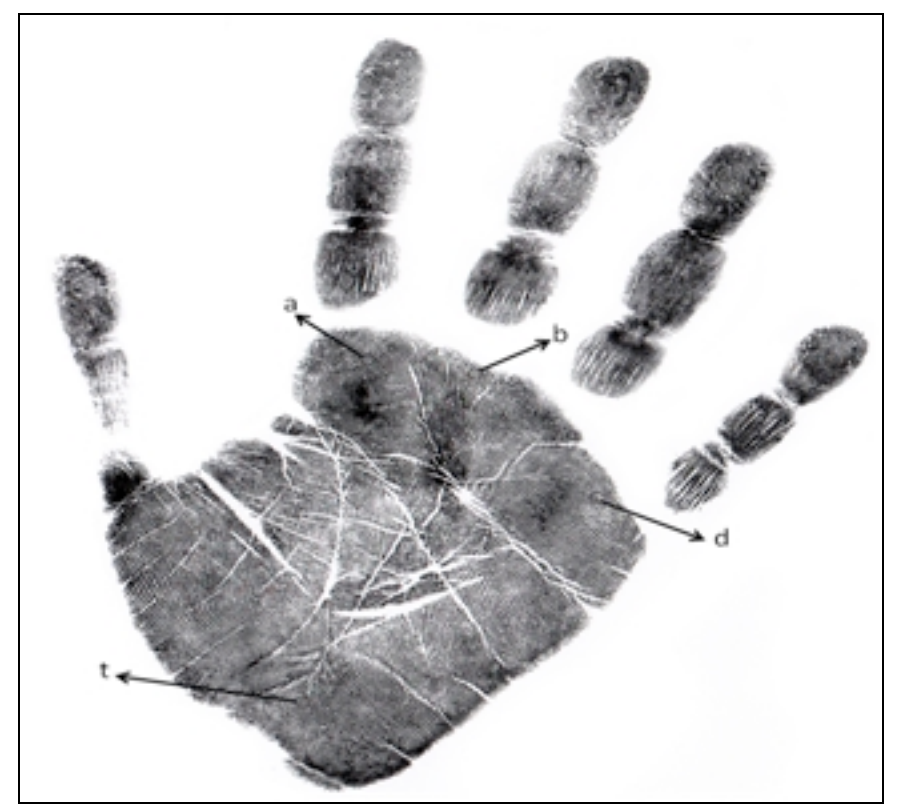

Figure 1b: Scanned palmprint photography of a child showing Triradii 'a', 'd', 'b' and 't'. 


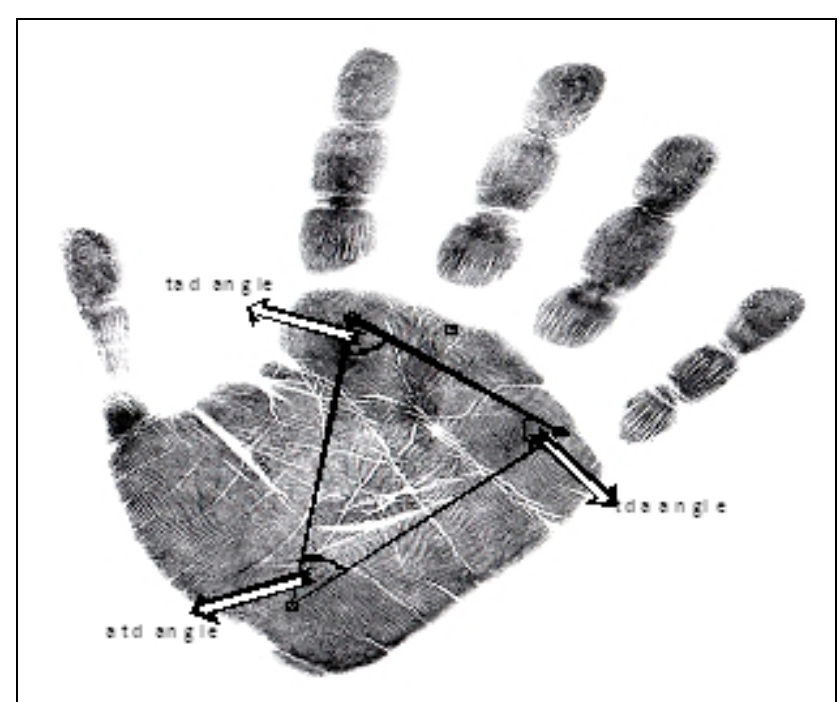

Figure 2: Scanned palmprint photography of a child showing three lines connecting triradii ' $a$ ', ' $d$ ' and ' $t$ ' forming three angles; atd, tad and tda.

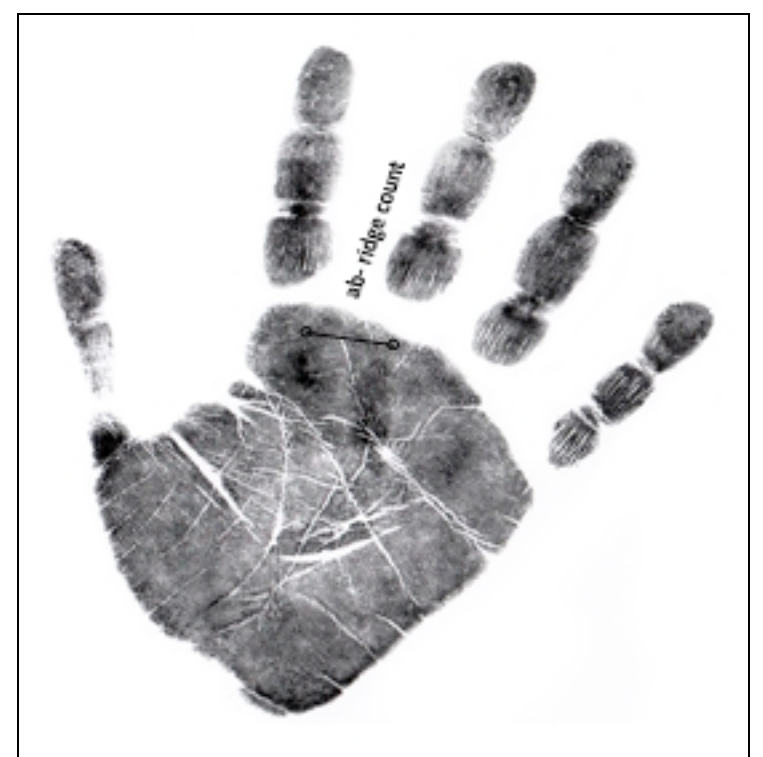

Figure 3: Scanned palmprint photography of a child showing the line connecting triradii 'a' and ' $b$ '. The number of ridges crossing this line was counted (ab- ridge count).

\section{Results}

The age of the studied patients and control groups ranged from 2.5 to10 years with a mean of $6.0 \pm 2.3$ years. $30 \%$ of them aged from $4-6$ years. As regards sex of the studied groups, $68.0 \%$ of them were males $(n=34)$ and $32.0 \%$ were females $(n=16)$.

Table (1) and (2) showed no significant differences between both hands as regards the mean atd, tad, adt angle measurements and ab-ridge count in the control and patients groups ( $\mathrm{p} \geq 0.05$ ).

Table (3) shows that angles atd and tad, and ab- ridge count were significantly greater among the control group, while no significant difference was noted as regards adt angle where $\mathrm{p}=0.030,0.032$, 0.036 and 0.0494 respectively.

By comparing the same parameters between patients and control groups in the left hand, it was found that angles atd, adt and ab-ridge count were significantly greater in the control group (where $\mathrm{p}=$ $0.01,0.04,0.03$ respectively). Angle tad was noted to be greater among the patients group than the control group where $\mathrm{p}=0.02$ (table 4$)$.

Multivariate analysis (ANOVA) was done to select the variable that can be used in developing an equation a screening tool for early prediction of leukemia. It is as follows:

$\mathrm{Y}=0.789+(0.002 *$ Left atd $)+(0.014 *$ Left tad $)+$ $(0.002 *$ Left ab-ridge count $)+(0.005 *$ Right atd $)-$

$(0.015 *$ Right tad $)+(0.009 *$ Right ab- ridge count $)$.

If $\mathrm{Y}<1.500$ the disease not found, If $\mathrm{Y}>1.50$ the disease present.

Accuracy 66.7\%. 
Table (1): Student " $t$ " test showing comparison between the right and left hand measurements among the control group $(n=50)$.

\begin{tabular}{|c|c|c|c|}
\hline - & Right hand & Left hand & $\mathbf{p}$ \\
\hline $\begin{array}{l}\text { Angle atd }\left(^{\mathbf{0}}\right) \\
\text { Range } \\
\text { Mean } \\
\text { S.D. }\end{array}$ & $\begin{array}{l}36-65 \\
47.4 \\
7.5\end{array}$ & $\begin{array}{l}39-71 \\
49.3 \\
8.8 \\
\end{array}$ & 0.121 \\
\hline $\begin{array}{l}\text { Angle tad }\left(^{\mathbf{0}}\right) \\
\text { Range } \\
\text { Mean } \\
\text { S.D. }\end{array}$ & $\begin{array}{l}38-78 \\
58.7 \\
9.5\end{array}$ & $\begin{array}{l}35-67 \\
54.6 \\
7.7\end{array}$ & 0.070 \\
\hline $\begin{array}{l}\text { Angle adt }\left(^{\circ}\right) \\
\text { Range } \\
\text { Mean } \\
\text { S.D. }\end{array}$ & $\begin{array}{l}56-89 \\
77.2 \\
6.6\end{array}$ & $\begin{array}{l}68-91 \\
78.6 \\
6.0\end{array}$ & 0.131 \\
\hline $\begin{array}{l}\text { ab- ridge count } \\
\text { Range } \\
\text { Mean } \\
\text { S.D. }\end{array}$ & $\begin{array}{l}32-55 \\
42.1 \\
5.0\end{array}$ & $\begin{array}{l}33-52 \\
41.1 \\
3.9\end{array}$ & 0.148 \\
\hline
\end{tabular}

$* P \leq 0.05$ : significant; $P \geq 0.05$ : non-significant.

Table (2): Student "t" test showing comparison between right and left hand measurements among patients with acute lymphoblastic leukemia $(n=50)$.

\begin{tabular}{|l|l|l|l|}
\hline & Right hand & Left hand & p \\
\hline Angle atd (') & & & \\
Range & $31-61$ & $28-72$ & \\
Mean & 44.6 & 45.5 & 0.271 \\
S.D. & 7.1 & 7.6 & \\
\hline Angle tad (') & & & \\
Range & $38-64$ & $41-74$ & 0.062 \\
Mean & 55.5 & 57.6 & \\
S.D. & 7.2 & 6.4 & \\
\hline Angle adt (') & & & \\
Range & $66-94$ & $54-89$ & 0.292 \\
Mean & 77.2 & 76.6 & \\
S.D. & 5.7 & 5.6 & \\
\hline ab-ridge count & & & \\
Range & $32-50$ & $22-54$ & 0.180 \\
Mean & 40.2 & 39.1 & \\
S.D. & 5.3 & 6.2 & \\
\hline
\end{tabular}

$* P \leq 0.05$ : significant; $P \geq 0.05$ : non-significant.

Table (3): Student " $t$ " test comparison between right hand measurements among patients and control groups $(\mathbf{n}=\mathbf{5 0}$ each).

\begin{tabular}{|c|c|c|c|}
\hline & Patients $(n=50)$ & Control $(n=50)$ & $\mathrm{P}$ \\
\hline $\begin{array}{l}\text { Angle atd }\left(^{\circ}\right) \\
\text { Range } \\
\text { Mean } \\
\text { S.D. }\end{array}$ & $\begin{array}{l}31-61 \\
44.6 \\
7.1\end{array}$ & $\begin{array}{l}36-65 \\
47.4 \\
7.5\end{array}$ & $0.030 *$ \\
\hline $\begin{array}{l}\text { Angle tad }\left(^{\circ}\right) \\
\text { Range } \\
\text { Mean } \\
\text { S.D. }\end{array}$ & $\begin{array}{l}38-64 \\
55.5 \\
7.2 \\
\end{array}$ & $\begin{array}{l}38-78 \\
58.7 \\
9.5\end{array}$ & $0.032 *$ \\
\hline $\begin{array}{l}\text { Angle adt }\left(^{\mathbf{0}}\right) \\
\text { Range } \\
\text { Mean } \\
\text { S.D. }\end{array}$ & $\begin{array}{l}66-94 \\
77.2 \\
5.7\end{array}$ & $\begin{array}{l}56-89 \\
77.2 \\
6.6\end{array}$ & 0.494 \\
\hline $\begin{array}{l}\text { ab- ridge count } \\
\text { Range } \\
\text { Mean } \\
\text { S.D. }\end{array}$ & $\begin{array}{l}32-50 \\
40.2 \\
5.3\end{array}$ & $\begin{array}{l}32-55 \\
42.1 \\
5.0\end{array}$ & $0.036^{*}$ \\
\hline
\end{tabular}

$* P \leq 0.05$ : significant; $P \geq 0.05$ : non-significant. 
Table (4): student" t" test showing comparison between left hand measurements among patients and control group $(n=50$ each).

\begin{tabular}{|c|c|c|c|}
\hline & Patients $(n=50)$ & Control $(n=50)$ & $\mathbf{p}$ \\
\hline $\begin{array}{l}\text { Angle atd ( }\left(^{\mathbf{}}\right) \\
\text { Range } \\
\text { Mean } \\
\text { S.D. } \\
\end{array}$ & $\begin{array}{l}28-72 \\
45.5 \\
7.6\end{array}$ & $\begin{array}{l}39-71 \\
49.3 \\
8.8 \\
\end{array}$ & $0.01 *$ \\
\hline $\begin{array}{l}\text { Angle tad (') } \\
\text { Range } \\
\text { Mean } \\
\text { S.D. }\end{array}$ & $\begin{array}{l}41-74 \\
57.6 \\
6.4\end{array}$ & $\begin{array}{l}35-67 \\
54.6 \\
7.7 \\
\end{array}$ & $0.02 *$ \\
\hline $\begin{array}{l}\text { Angle adt }\left(^{\mathbf{}}\right) \\
\text { Range } \\
\text { Mean } \\
\text { S.D. }\end{array}$ & $\begin{array}{l}54-89 \\
76.6 \\
5.6\end{array}$ & $\begin{array}{l}68-91 \\
78.6 \\
6.0\end{array}$ & $0.04 *$ \\
\hline $\begin{array}{l}\text { ab- ridge count } \\
\text { Range } \\
\text { Mean } \\
\text { S.D. }\end{array}$ & $\begin{array}{l}22-54 \\
39.1 \\
6.2\end{array}$ & $\begin{array}{l}33-52 \\
41.1 \\
3.9\end{array}$ & $0.03 *$ \\
\hline
\end{tabular}

$* P \leq 0.05$ : significant; $P \geq 0.05$ : non-significant.

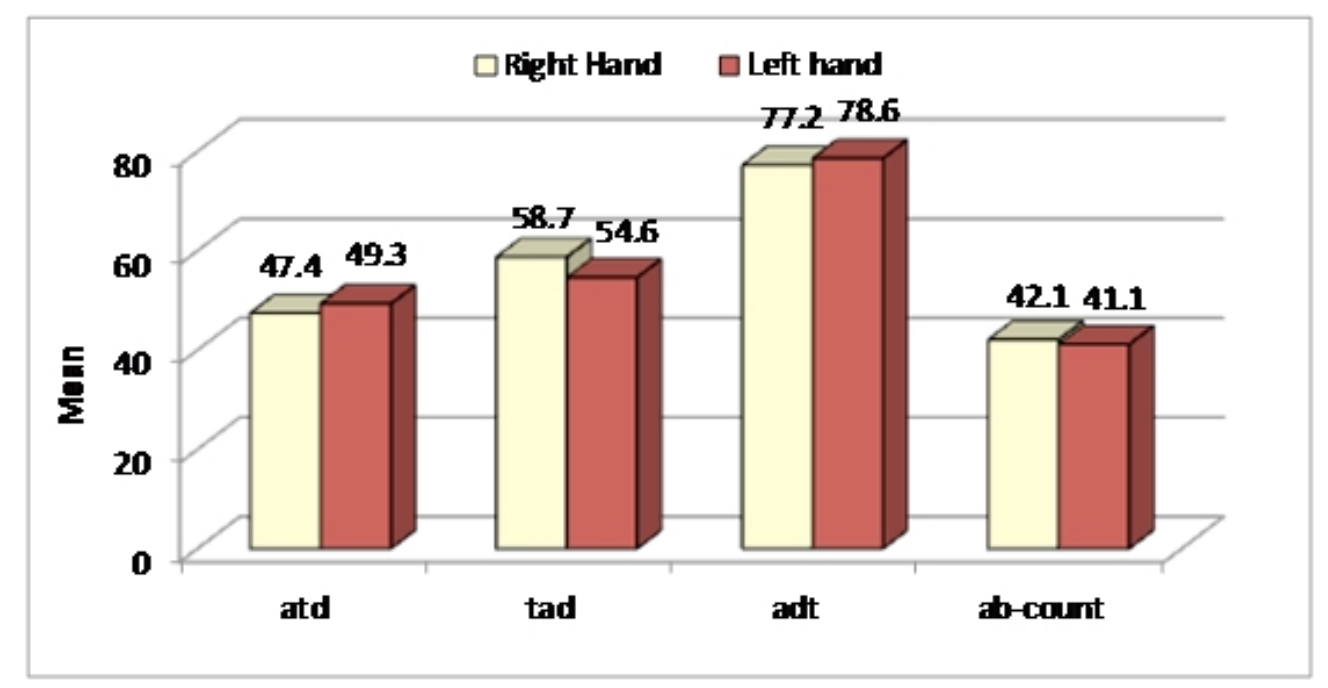

Figure 4: Histogram comparison between right and left hand mean measurements among the control group $(\mathbf{n}=\mathbf{5 0})$.

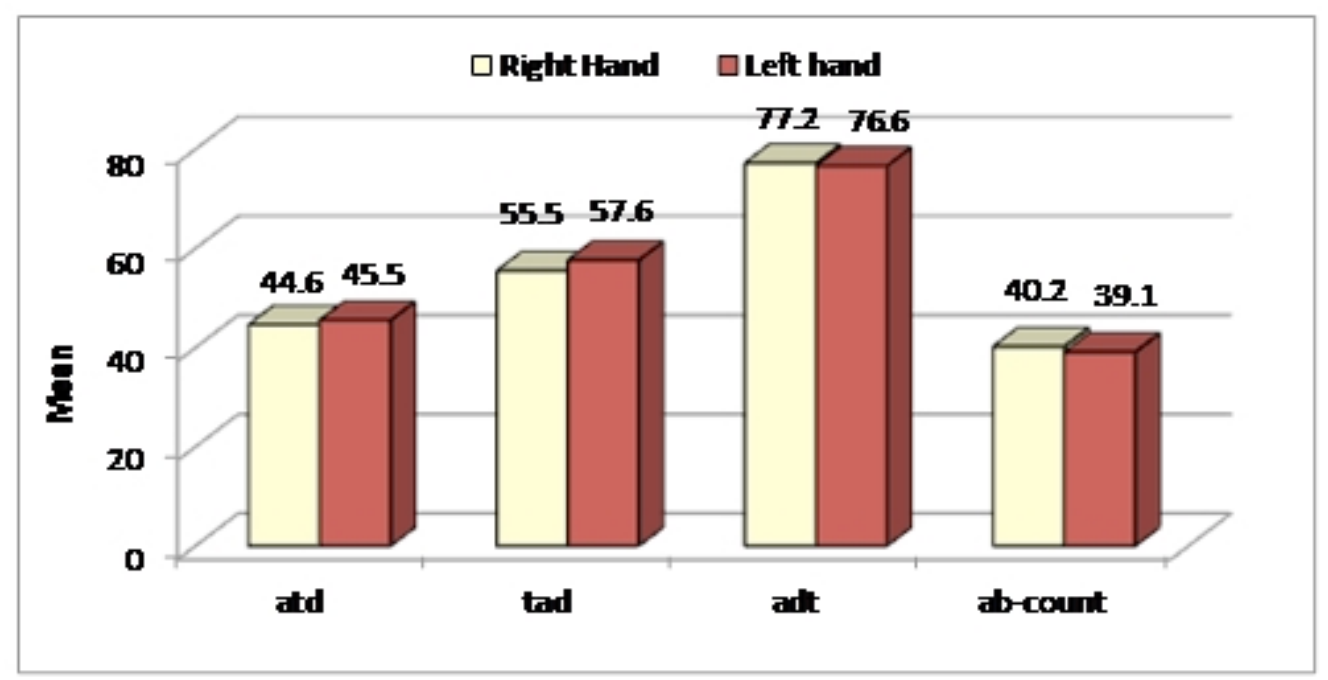

Figure 5: Histogram comparison between mean right and left hand measurements among patients with acute lymphoblastic leukemia $(n=50)$. 


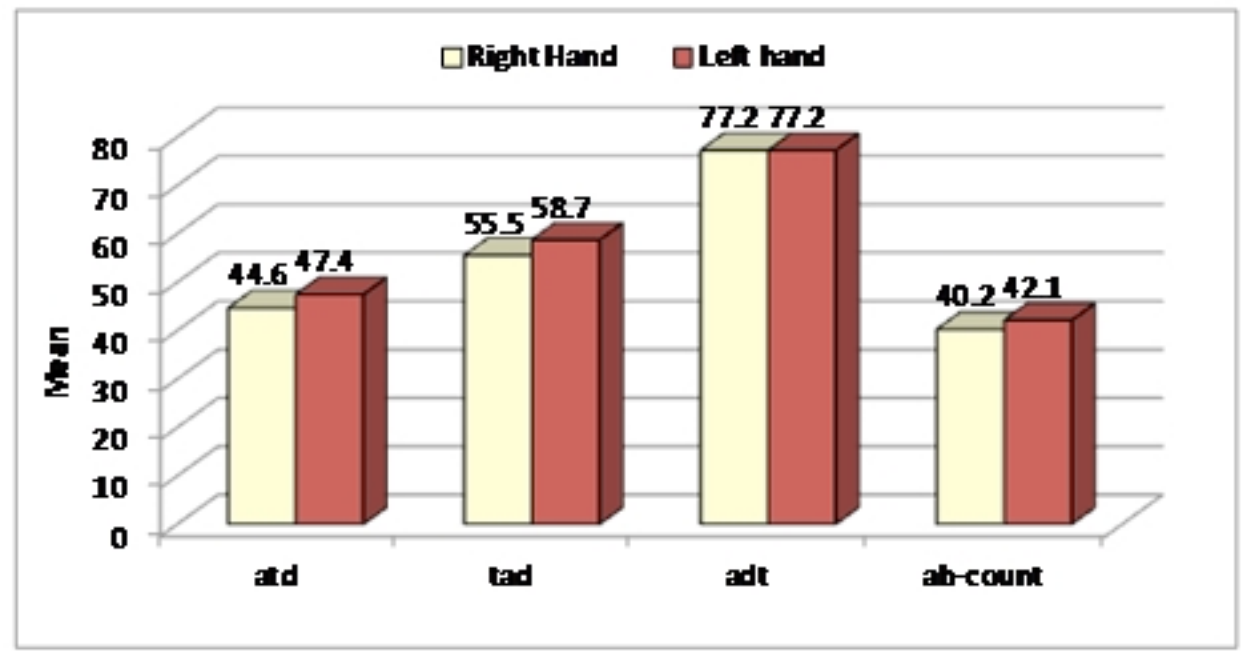

Figure 6: Histogram comparison between mean right hand measurements among patients and control groups $(n=50$ each $)$.

\section{Discussion}

A remarkable understanding of dermatoglyphics has been gained and analysis of dermal ridges could be used in diagnosis of some diseases. Since it was found that patients with chromosomal anomalies have uncommon fingerprints, this science was focused on genetic diseases and made enormous progress (Kelliher et al., 2005 and Nousbeck et al., 2011). The use of analytical methods and computer in analysis of dermatoglyphics has increased utilization of dermatoglyphics in medicine (Nezhad and Shah, 2010).

The relation between characteristic dermatoglyphics and medical genetically based diseases could be explained by the fact that dermal ridge differentiation takes place in the first trimester of fetal development and its configurations are genetically determined. Although ridge configurations can be modified or influenced by environmental factors, yet they remain unchanged throughout the whole life (Karmakara et al, 2008). This relation can also be considered as a window of congenital abnormalities and a sensitive indicator of intrauterine anomalies (Cowger, 1993).

This was the explanation of relating characteristic dermatoglyphics with certain medical genetically based diseases e.g. Kleinfelter's syndrome (Cowger, 1993), cerebral palsy (Proloscic et al. (2009), Down syndrome (trisomy 21) (Barbosa et al., 2009), diabetes mellitus (Nezhad and Shah, 2010) and bronchial asthma (Maceo, 2011).

These studies tried to add dermatoglyphics as logical extension of the physical examination of the patient, where it can be an easy, cheap, noninvasive method to predict a certain disease (Sridevil et al,. 2010)
The present study is concerned with acute lymphoblastic leukemia, which is proved to be based on a genetic factor (e.g. aberration of Philadelphia chromosome). Cellular aberration in cases of leukemia is mesodermal in origin and its development occurs from the third to eighth week of fetal development, known as an embryonic period.

Dermatoglyphics development begins nearly at the same time (fifth to sixth week of fetal development). It originates as an interaction between ectoderm (skin) and mesoderm (dermis and subcutaneous tissue) (Wertheim, 2011). Therefore any aberration in cellular structure of blood forming cells may also leads to change in dermatoglyphics of the same person.

The aim of the present work was to find a relation between acute lymphoblastic leukemia and characteristic dermatoglyphics among the Egyptian children. This can help many children through early diagnosis of the disease and consequently early treatment that almost affect their prognosis.

Dermatoglyphics parameters had been measured by multiple studies using ruler and protractor with the aid of magnifying glass. Some of them recommended using software programs for more accurate results (Sridevil et al, 2010 and Wertheim, 2011).

In the present study certain palmprint dermatoglyphics parameters were measured in patients and control groups. These parameters are: atd, adt, tad angles, and ab-ridge count.

No statistical significant difference was found between the right and left hands in both patients and controls. Similar results were obtained by Bukelo et al, (2011). 
Measurements of angle (atd) took much concern from researchers in palmprint analysis, especially in studies correlating palmprint with medical diseases. In the current work, statistical significant difference was found between patients and control group as regards this angle where it was higher among the control group. However Bukelo et al., (2011) found that mean (atd) angle was higher among children with (ALL) patients than the control group. This difference could be contributed to racial and environmental factors.

Angle (atd) was found to be greater in other diseases as in cases of turner syndrome (45, XO) (Maskey et al , 2007), Kleinfelter syndrome (47, XXY) (Sontakke et al. , 2010), Down syndrome (trisomy 21) and diabetes mellitus (Wertheim, 2011). While it was found to be smaller in cases of cancer cervix (Inamdar et al., 2006) and prostate cancer (Oladipo et al., 2009). Researches done on breast cancer showed that atd angle is not significantly different between patients and control groups (Sridevil et al., 2010).

The results of this work also demonstrated that the mean tad angle in the right hand of the control group was greater than that of patients group. While the (tad) angle of the left hand of the patients group was greater than that of the control group. Bukelo et al., 2011 found that this angle (tad) is apparently marginal between the cases and control groups in both hands, but their results were not based on statistical analysis. Measurement of angle (adt) was found to have no significant difference between patients and control groups in the right hand while in the left hand, it showed to be significantly greater among the control group. The same was recorded by Bukelo et al., 2011 where they found that (adt) angle was greater among the control group in both hands.

In this work, ab- ridge count was significantly greater among the control group in right and left hands than the patients group. In contrast to the finding of this study Bukelo et al., 2011 found that mean ab-ridge count was greater among the patients group.

Studies concerned with palmar dermatoglyphics found ab- ridge count greater in cases of breast and prostate cancer (Oladipo et al., 2009). Others demonstrated that it is significantly smaller in cases of diabetes mellitus (Fogle, 1990), and rheumatoid arthritis (Wertheim, 2011), while it was shown to be non-significantly different in cases of cancer cervix (Inamdar et al., 2006).

Trial was made to develop an equation to be used for prediction of acute lymphoblastic leukemia where significant parameters in the study were taken in consideration.

$$
\begin{gathered}
Y=0.789+(0.002 * \text { Lt. atd })+(0.014 * \text { Lt.tad })+ \\
(0.002 * \text { Lt.ab-ridge count })+(0.005 * \text { Rt. atd })- \\
(0.015 * \text { Rt.tad })+(0.009 * \text { Rt. ab- ridge count }) .
\end{gathered}
$$

If $\mathrm{Y}<1.500$ : the disease not found, if $\mathrm{Y}>$ 1.50: the disease present.

The overall accuracy in disease prediction was $66.7 \%$.

\section{Recommendations}

Based on the present study, the following recommendations are proposed:

- The study of dermatoglyphics can be applied as a routine clinical screening method for the early diagnosis of certain diseases resulting from genetic aberrations.

- The use of software programs for analysis of palmprint measurements gives better and accurate results than using magnifying glass and protractor.

- Similar studies are suggested on other types of leukemia.

- Other parameters of the palmprint and fingerprint patterns among acute lymphoblastic leukemic children could be considered, to find any relationship between them. In trial to estimate different equations helping in prediction of the disease.

- Further studies should be done to assess the validity of this equation in other sectors of Egyptian population.

\section{References}

Barbosa EL, Fernandes PR and Fernandes FJ (2009): Anthropometry, muscular strength and dermatoglyphycs of individuals with Down's syndrome. Fit Perf J; 8:269-78.

Bukelo MJ, Kanchan T and Rau A (2011): Palmar dermatoglyphics in children with acute lymphoblastic leukemia -A preliminary investigation. J Forensic Leg Med; 18:115-8.

Caroll WL and Loh M (2011): The biology of acute lymphoblastic leukemia. In: Reaman GH and Smith FO (eds). Childhood leukemia: A practical handbook. Springer, USA, 29-62.

Chan YH (2004): Biostatistics 201: Linear Regression Analysis. Singapore Med J 45(2):55-61 
Cole SA (2001): A History of Fingerprinting and Criminal Identification.: Harvard University press, Cambridge .

Conter V, Rizzari C, Sala A, et al. (2004): Acute Lymphoblastic Leukemia. Orphanet Encyclopedia; 513:1-13.

Cowger JF (1993): Friction ridge skin comparison and identification of fingerprints. CRC press, California, 1-188.

Fogle, T (1990): Using dermatoglyphics from Down syndrome and class populations to study the genetics of a complex trait. In: Goldman CA(ed). Tested studies for laboratory teaching. Association for Biology Laboratory Education (ABLE),Nontre Dame, USA, 12950

Gordijn MS, Litsenburg RV, Gemke RB, et al. (2012): Hypothalamic-pituitary-adrenal axis function in survivors of childhood acute lymphoblastic leukemia and healthy controls. Psychoneuroendocrino; 37: 1448-56.

Inamdar VV, Vaidya SA, Kulkarni P, et al. (2006): Dermatoglyphics In Carcinoma Cervix. J.Anat.Soc. India; 55 (1):57-9.

Karmakara B, Yakovenkob $\mathrm{K}$ and Kobyliansky E (2008): Quantitative digital and palmar dermatoglyphics: Sexual dimorphism in the Chuvashian population of Russia. HOMOJournal of Comparative Human Biology; 59: 317-28.

Kelliher TP, Rittscher $\mathrm{J}$ and Tu P. (2005): Identification. In: James JP (ed). Encyclopedia of forensic and legal medicine. Elsevier, USA, $1-12$.

Kern WF (2002): PDQ hematology. Canada: BC Decker, 1-23.

Maceo AV (2011): Anatomy and physiology of adult friction ridge skin. In: Holder EH, Robinson LO and Laub JH (eds). Fingerprint source book. National institute of justice, Washington, 1-26.

Maskey D,Bhattacharya S,Dhungel S, et al. (2007): Utility of phenotypic dermal indices in the detection of down syndrome Patients. Nepal Med Coll J.; 9(4):217-21.

Nezhad HR and Shah NM. (2010): Application of Dermatoglyphic Traits for Diagnosis of Diabetic Type 1 Patients. Int J Environ Sci D; $1: 36-9$.
Nousbeck J, Burger B, Pavlovsky M, et al. (2011); A Mutation in a Skin- Specific Isoform of SMARCAD1 Causes Autosomal-Dominant Adermatoglyphia. The American Journal of Human Genetics; 89:302-7.

Oladipo GS, Olotu EJ, Fawehinmi HB, et al. (2007): Dermatoglyphics in idiopathic (primary) dilated cardiomyopathy in South Southern Nigeria. Sci Res Essays; 2 (10): 416-20

Oladipo GS, Sapira MK, Ekeke ON, et al. (2009): Dermatoglyphics of Prostate Cancer Patients. Current Research Journal of Biological Sciences; 1(3):131-4.

Proloscic TP, Milicic J, Cvjeticanin M, et al. (2009): Comparison of Digito-Palmar Dermatoglyphic Traits in Children with Cerebral Palsy and Their Close Family Members. Coll Anthropol; 3:925-31.

Ravandi F and Kebriaei P (2009): Philadelphia Chromosome-Positive Acute Lymphoblastic Leukemia. Hematol Oncol Clin N Am; 23:1043- 63 .

Schauman B and Alter M (1976): Dermatoglyphics in medical disorders ( $1^{\text {st }}$ edition); springerVerlag, New York, 7

Seiger J, Saukko P and Knupfer G (2008): Encyclopedia of forensic science. Elsevier, USA, 871-7

Sontakke BR, Ghosh SK and Pal AK (2010): Dermatoglyphics of fingers and palm in Klinefelter's syndrome. Nepal Med Coll J; $12: 142-4$

Sridevil NS, silvia WD, kulkarni R, et al. (2010): Palmar dermatoglyphics in carcinoma Breast of indian women. Romanian journal of morphology and embryology; 51(3):547-50

Wang JF, Lin CL and Yen CW (2008): Determining the association between dermatoglyphics and schizophrenia by using fingerprint asymmetry measures. Int J Pattern Recognition; 22: 601-16

Wertheim K (2011): Embryology and morphology of friction ridge skin. In: Holder EH, Robinson LO and Laub JH, (eds). Fingerprint source book. National institute of justice, Washington, 1-26. 
الملخص العربي

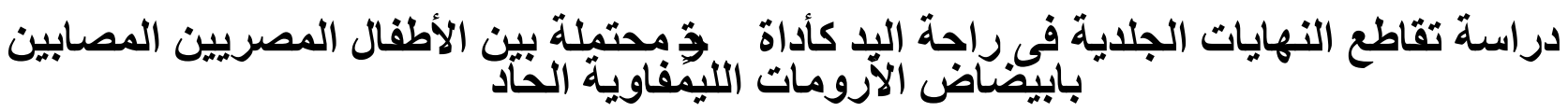

نجلاء سلامة1 و سمية مدكور 1 و أمينة الحلواني² نرمين عبد الحق1 1

البصمات هى دراسة نمط الأحرف الاحتكاكية بجلد راحة البد و الأصابع و أخمص القدم و إصابع القدام. يتم

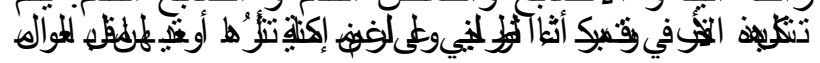

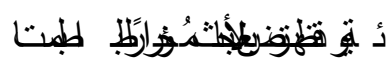

البيئية إلا انها تبقى بعد الو لادة دون تغبير مدى الحياة.

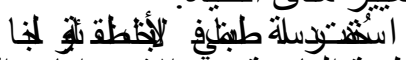

بالأنثروبولوجيا وبعض الأمر اض الطبية الناتجة عنّ الأنحر افتات الجينية.

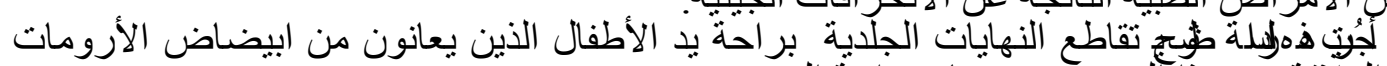

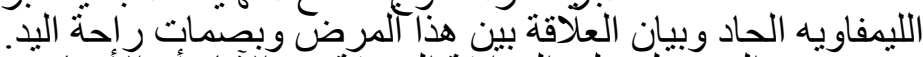

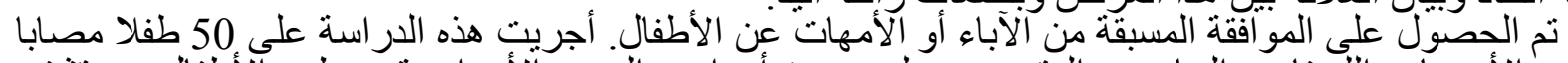

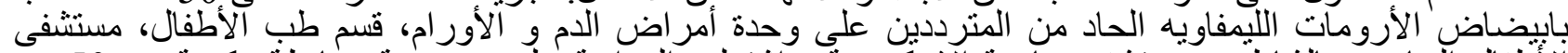

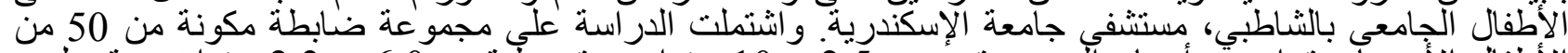

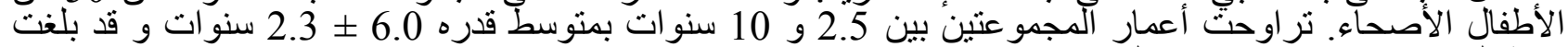

نسبة الذكور 68\% بينما الإناث بلغت نسبته

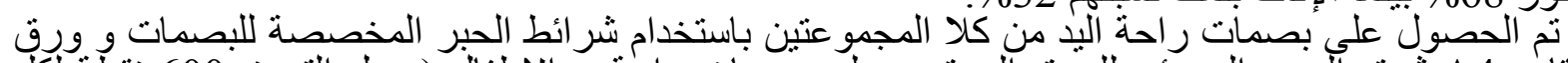

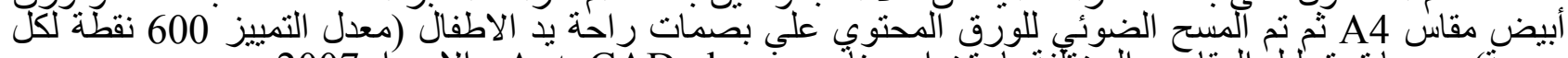

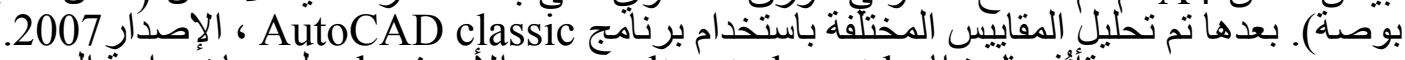

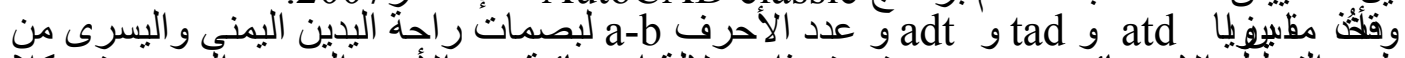

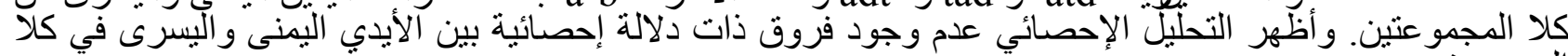

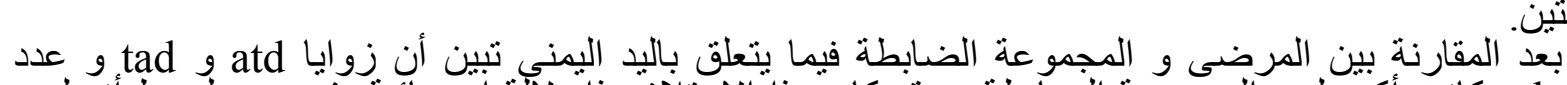

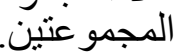

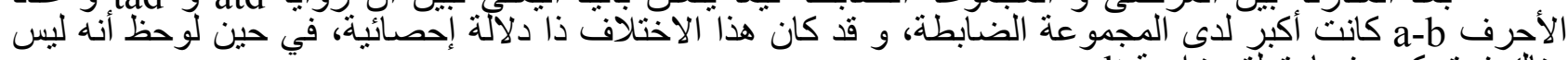

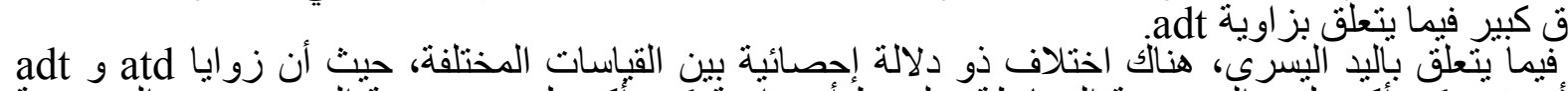

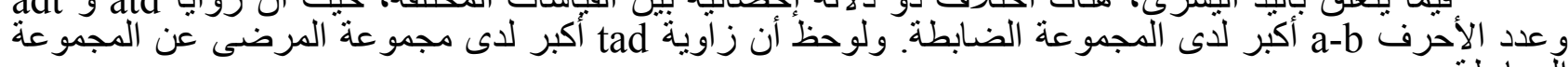

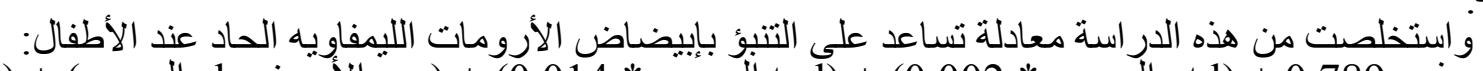
الضابطة.

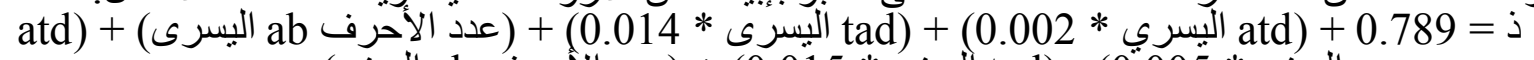

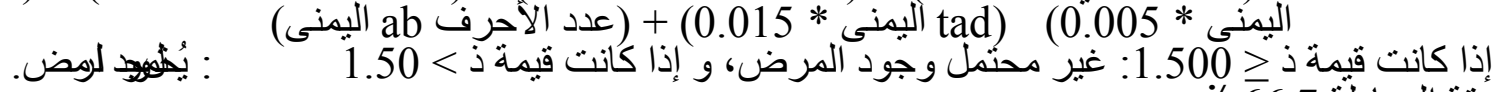

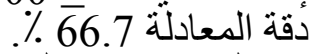

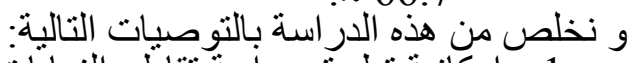

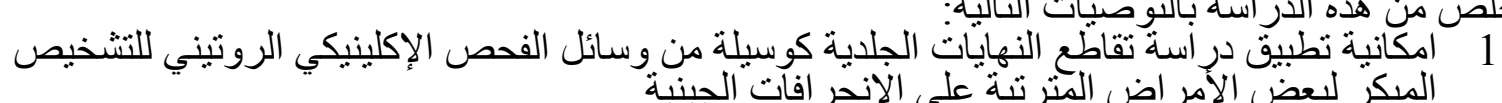

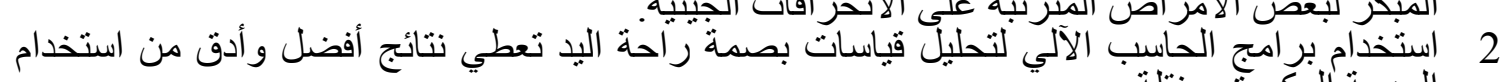

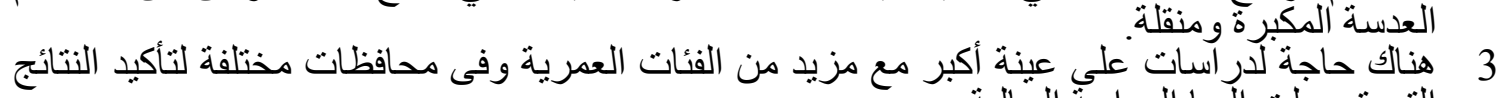

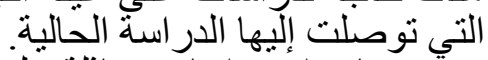
4

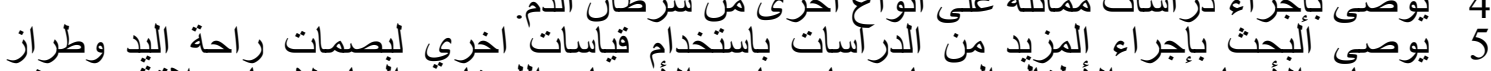

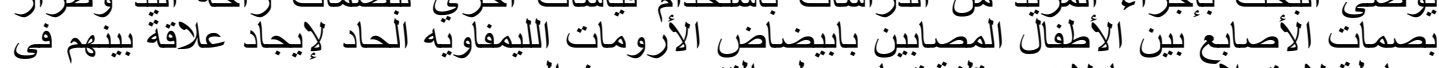

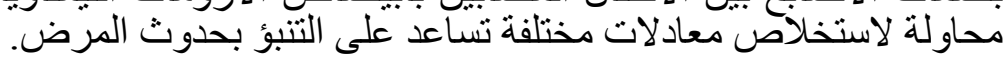

1 قسم الطب الثرعي والسموم الإكلينيكية كلية الطب جامعة الإسكندرية

2 قسم طب الأطفال كلية الطب جامعة الإسكندرية 